\title{
RAPUNZEL SYNDROME WITH REVERSE INTUSSUSCEPTION MANAGED BY LAPAROSCOPY: CASE REPORT
}

Mangesh Panse1, Sanjay Padale², Anirudha Mandhane³, Pankaj Bhalerao4.

HOW TO CITE THIS ARTICLE:

Mangesh Panse, Sanjay Padale, Anirudha Mandhane, Pankaj Bhalerao. "Rapunzel syndrome with reverse intussusception managed by laparoscopy: case report". Journal of Evolution of Medical and Dental Sciences 2013; Vol2, Issue 28, July 15; Page: 5127-5135.

ABSTRACT: BACKGROUND AND OBJECTIVES: Rapunzel syndrome is a rare type of trichobezoars with an extension of the hair into the small bowel. Clinical presentation is deceptive and vague ranging from abdominal mass to gastrointestinal symptoms. Standard treatment of large gastric bezoars not amenable to medical or endoscopic management is surgical removal. The optimal operative approach, laparotomy versus laparoscopy, is a contested subject. Though laparoscopic removal has been described, it remains a relatively new technique for surgical management with outcome literature limited to case reports. In addition, currently described laparoscopic techniques often involve limited midline laparotomy incisions or $4 \mathrm{~cm}$ extensions of port sites.

A case report of trichobezoars in the stomach causing Rapunzel syndrome with reverse intussusception in a 19-year-old female is reported.

KEYWORDS: Trichobezoar, Trichophagia, Rapunzel syndrome, Reverse intussusception

INTRODUCTION: Bezoar is a tightly packed collection of undigested material that is unable to exit the stomach, Most bezoars are of indigestible organic matter such as hair-trichobezoars; or vegetable and fruit the - phytobezoars; or a combination of both but other rare substances has been also been described in literature. Trichobezoars, commonly occur in patients with psychiatric disturbances who chew and swallow their own hair. Only 50\% will have history of trichophagia. Trichobezoars have been described in literature and they comprise $55 \%$ of all bezoars. In very rare cases the Rapunzel Syndrome hair extends through the pylorus into the small bowel causing symptom and sign of partial or complete gastric outlet obstruction. ${ }^{1}$

Traditionally, bezoars are removed by laparotomy; however, because of recent reports, laparoscopic removal is slowly growing as the choice of intervention.

CASE REPORT: A 19-year-old female came to our outpatient surgery department with a vomiting and dragging pain in her upper abdomen over past 6 months. Despite the treatment she was receiving there was no improvement in her condition, in fact she was getting worse. She was malnourished with thin brittle hair and was mildly pale. The patient had no history of hematemesis, or melena. The rest of her general and abdominal examination was unremarkable. Abdominal ultrasonography showed an echogenic mass in the stomach; however, no definite diagnosis could be made\& also multiple reverse intussusception. She underwent contrast enhanced computed tomography of the abdomen (CECT), which showed a nonenhancing mixed density intraluminal gastric mass with foci of air and oral contrast (Figure 1). The mass was circumscribed by oral contrast, suggesting a trichobezoars. An endoscopy was also done to confirm the diagnosis. 
LAPAROSCOPIC REMOVAL TECHNIQUE: The patient underwent laparoscopic trichobezoars removal from her stomach. She was operated on while in the Lloyd-Davis position with a $30^{0}$ reverse Trendelenburg tilt. A $10-\mathrm{mm}$ infraumbilical camera port was established for a 5-mm $30^{\circ}$ telescope along with 2 more $6-\mathrm{mm}$ ports at the left lumbar region at the level of the umbilicus and $11 \mathrm{~mm}$ at the right lumbar region. After inspecting peritoneal cavity multiple reverse intussusception (Figure 2)were found\& reduced laparoscopically. A gastrostomy was done over the anterior wall of the stomach by using ultrasonic scissors. The stomach contents were aspirated, and the bezoar mobilized inside the stomach by using the 5 -mm suction cannula. The apex of the gastric rent was elevated with a grasper through the left port while the bezoar was mobilized from the fundus holding it with a 10-mm claw forceps (Figure 3). Once the proximal end of the bezoar came out of the stomach, the hard bezoar was again lifted with the claw forceps (Figure 4) to totally remove it from the stomach (Figure 5). The stomach was irrigated, and both ends were examined for any residue. The laparoscope could be inserted through the gastric rent proximally into the fundus of the stomach and distally into the first part of the duodenum through the left lumbar port, which seemed to be a distinct advantage over conventional open surgery. This procedure confirmed the absence of any small residues. The bezoar was removed through a 4-cm upper midline incision (Figure 6) with completely removed specimen (Figure 7) and the anterior gastric wall sutured extracorporeally through it. The abdominal retrieval incision was closed and pneumo-peritoneum was re-achieved, which allowed us to check the sutured gastric rent and copiously irrigate the right and left subphrenic and paracolic spaces. The patient had a prolonged ileus in her postoperative period, and on her third postoperative day a mild discharge was seen from her main retrieval wound, which subsided within 2 days.

DISCUSSION: Bezoars are classified into 4 main types, according to the materials of which they are composed: Phytobezoars, Trichobezoars, medication bezoars, and lacto-bezoars. Most common are phytobezoars that consist of indigestible fruits, vegetable fibers, skin, or seeds. ${ }^{3}$ Phytobezoars are classically found in adults with a history of previous gastric surgery, conditions of reduced gastric acidity, poor gastric mixing, or delayed motility. Trichobezoars, or hairballs, are a mass of hairs, decaying food material or both. Medication bezoars consist of undigested tablets or semiliquid drugs. Lacto-bezoars are frequently found in low birth- weight or premature neonates fed with a highly concentrated formula within the first weeks of life. ${ }^{3}$ Bezoars usually $(90 \%)$ are found in children and youngfemales ${ }^{2}$ with pica, psychiatric disorders, or mental retardation, but rarely a severe psychiatric disorder is seen. ${ }^{3}$

Usually there are no symptoms until the trichobezoars reaches a substantial size. ${ }^{4}$ An indentable abdominal mass is the commonest presentation, ${ }^{5}$ with other features like alopecia circumscripta and signs of gastric outlet obstruction. ${ }^{4}$ Gastric bezoar formation occurs in patients with altered gastric physiology, impaired gastric emptying, reduced acid production, or all of these together. This is usually caused by previous gastric surgery, such as partial gastrectomy, vagotomy, or pyloroplasty, but may be caused by gastroparesis or gastric outlet obstruction. Contributing factors can include dysmotility of the gastrointestinal tract, dehydration, malnutrition, and diabetes mellitus. After antrectomy, the incidence is as high as $10 \%$ to $25 \% .^{3}$ Poor mastication and ingestion of large quantities of indigestible solids may also precipitate bezoar formation. ${ }^{3}$ Trichobezoar can be associated with Me'ne'trie`r's disease and pancreatitis. ${ }^{4}$ There also can be associated 
intussusception. Ultrasound features are not confirmatory; however, an arc-like surface echo casting a clear posterior acoustic shadow with dilated lumen can suggest the diagnosis. ${ }^{4}$ Barium can show a cast of the stomach. CECT scan has a high accuracy rate and differentiates it from any neoplasms.5,6 CECT scan shows a well-circumscribed ovoid intraluminal lesion, composed of concentric whorls of different densities with pockets of air enmeshed within it, appearing in the stomach region. Beyond the lesion, the bowel collapses. ${ }^{4}$ Oral contrast fills the more peripheral interstices of the lesion, and a thin band of contrast circumscribes it. Absence of significant post-intravenous contrast enhancement precludes a neoplastic lesion. ${ }^{4}$ Endoscopy confirms the diagnosis and often the offending bezoar can be removed by this route. ${ }^{3}$ Trichobezoar has a black color that is seen due to denaturation of proteins and gives a foetid odor due to entrapment of undigested fat in the hair mesh with bacterial colonization. ${ }^{3}$ Currently accepted treatment of bezoars, include observation, dissolution, fragmentation, and laparotomy and gastrotomy. ${ }^{1}$ Beyond these other modalities, gastroscopic fragmentation, nasogastric lavage or suction, and enzymatic therapy with cellulose and papain have beentried.6,7 Endoscopy is also known to have a therapeuticpotential. ${ }^{4}$ Endoscopy can be difficult and risky with a few cases of esophageal perforation reported in the literature. ${ }^{3}$ Endoscopic irrigation with Coca Cola ( $\mathrm{NaHCO} 3$ ) can have a mucolytic effect in removing trichobezoars. ${ }^{2}$ Other minimally invasive modalities like extracorporeal lithotripsy, endoscopic lithotripsy, and laser fragmentation are emerging. Their role, success rates, and complications need to be defined. ${ }^{4,7}$

Therapeutic laparoscopy is fast emerging and has been demonstrated to be feasible, though difficult in the management of gastric bezoars. ${ }^{1,5-10}$ Theoretically, $80 \%$ of abdominal operations could be performed laparoscopically. ${ }^{1}$ Laparoscopy is associated with minimal incision, less pain, reduced hospital stay, excellent cosmetic out- come, and fewer complications compared with the openprocedure. 8,10 Authors have described their techniques with 3 to 5 ports (Table 1). Controversy exits regarding the method of retrieval. Most authors advocate piecemeal removal over in toto removal. The greatest risk of contamination is at the time of gastrostomy and during its transfer into the endo-bag. ${ }^{9}$ Disadvantages of laparoscopy could be of longer operating time, higher costs, and problems with retrieval.1,7 Retrieval should always be in an endo-bag and piecemeal, or in toto removal depends on the size and weight of the bezoar. Impervious endobag is absolutely essential to prevent spillage and infection.

Comparisons have been made in small intestinal bezoars with laparoscopy and open surgery ${ }^{8}$ along with anecdotal reports of single cases. ${ }^{5}$, 11 It can present as an isolated mass or with satellite nodules causing interrupted obstruction. ${ }^{5}$ The ideal recommended procedure is to milk the bezoar beyond the ileo-cecal valve into the cecum; however, laparoscopic-assisted procedures are also commonly applied. Distention of proximal bowel can hamper visibility, and occasionally locating the intestinal bezoar is difficult in laparoscopy. ${ }^{11}$

The associations of pregnancy merits special mention, as bezoars are commonly seen in young females in the reproductive age group. Laparoscopy during pregnancy is never without the fear of harm, including spontaneous abortion of the developing fetus; however, increasing cumulative worldwide experience suggests that there is no significant difference in fetal morbidity with laparoscopy compared with laparotomy. ${ }^{9}$ 


\begin{tabular}{|c|c|c|c|c|c|c|}
\hline $\begin{array}{l}\text { Authors and } \\
\text { Year }\end{array}$ & Technique & $\begin{array}{l}\text { Gastrostomy } \\
\text { Closure }\end{array}$ & Retrieval & $\begin{array}{l}\text { Size of } \\
\text { Bezoar/ } \\
\text { Time }\end{array}$ & Recovery & Follow-up \\
\hline $\begin{array}{l}\text { Nirasawa et } \\
\text { al } \\
1998\end{array}$ & $\begin{array}{l}4 \text { ports, } \\
\text { Gastrostomy } \\
\text { with } \\
\text { electrocautery }\end{array}$ & $\begin{array}{l}\text { Intracorporeal } \\
\text { two } \\
\text { layered } \\
\text { closure }\end{array}$ & Direct & $\begin{array}{l}11 \mathrm{~cm}, \\
185 \mathrm{~g}, \\
300 \mathrm{~min}\end{array}$ & Uncomplicated & $\begin{array}{l}\text { Psychiatry OPD } \\
\text { follow up }\end{array}$ \\
\hline $\begin{array}{l}\text { Yao et al } \\
2000\end{array}$ & $\begin{array}{l}3 \text { Ports, } \\
\text { Anterior } \\
\text { longitudinal } \\
\text { gastrostomy }\end{array}$ & $\begin{array}{l}\text { Intracorporeal } \\
\text { two } \\
\text { layers }\end{array}$ & $\begin{array}{l}\text { Surgical } \\
\text { gloves, } \\
\text { Piecemeal }\end{array}$ & - & $\begin{array}{l}\text { Oral intake } \\
\text { POD3, } \\
\text { Uneventful } \\
\text { recovery }\end{array}$ & - \\
\hline $\begin{array}{l}\text { Shami et al } \\
2007\end{array}$ & $\begin{array}{l}\text { Supine, } 3 \\
\text { ports, } \\
\text { Anterior } \\
\text { gastrostomy } \\
\text { using } \\
\text { ultrasonic } \\
\text { scalpel }\end{array}$ & $\begin{array}{l}\text { Intracorporeal } \\
\text { Vicryl 2-0 }\end{array}$ & $\begin{array}{l}\text { Endobag, } \\
\text { Piecemeal }\end{array}$ & $\begin{array}{l}17 \mathrm{~cm}, \\
720 \mathrm{~g}, \\
220 \mathrm{~min}\end{array}$ & $\begin{array}{l}\text { Oral intake } \\
\text { POD1, } \\
\text { Discharge } \\
\text { POD3, Wound } \\
\text { infection }\end{array}$ & 1yr, Uneventfu \\
\hline $\begin{array}{l}\text { Palanivelu } \\
\text { et } \\
\text { al } 2007\end{array}$ & $\begin{array}{l}\text { Anterior } \\
\text { gastrostomy } \\
\text { with stay } \\
\text { sutures }\end{array}$ & $\begin{array}{l}\text { Through } \\
\text { abdominal } \\
\text { retrieval } \\
\text { incision }\end{array}$ & Endobag & - & $\begin{array}{l}\text { Oral intake } \\
\text { POD3, } \\
\text { Discharge } \\
\text { POD5 }\end{array}$ & $\begin{array}{l}\text { 2yrs, } \\
\text { Uneventful }\end{array}$ \\
\hline $\begin{array}{l}\text { Song et al } \\
2007\end{array}$ & $\begin{array}{l}4 \text { Ports, } \\
\text { Anterior } \\
\text { gastrostomy, } \\
\text { Monopolar } \\
\text { cautery }\end{array}$ & $\begin{array}{l}\text { Endo-GIA } \\
\text { staplers }\end{array}$ & $\begin{array}{l}\text { Endobag, } \\
\text { Piecemeal }\end{array}$ & $\begin{array}{l}7 \mathrm{~cm},- \\
50 \mathrm{~min}\end{array}$ & $\begin{array}{l}\text { Oral intake } \\
\text { POD3, } \\
\text { Discharge } \\
\text { POD6, } \\
\text { Uncomplicated }\end{array}$ & - \\
\hline $\begin{array}{l}\text { Meyer- } \\
\text { Rochow } \\
\text { et al } 2007\end{array}$ & $\begin{array}{l}\text { Lloyd Davis } \\
\text { position, } 5 \\
\text { ports, } \\
\text { Gastrostomy } \\
\text { with } \\
\text { electrocautery }\end{array}$ & $\begin{array}{l}\text { Intracorporeal } \\
\text { two } \\
\text { layers }\end{array}$ & $\begin{array}{l}\text { Endobag, } \\
\text { Piecemeal }\end{array}$ & $180 \mathrm{~min}$ & $\begin{array}{l}\text { Oral intake } \\
\text { POD2, } \\
\text { Discharge } \\
\text { POD3, } \\
\text { Uneventful }\end{array}$ & $\begin{array}{l}\text { Pregnancy } \\
\text { clinic }\end{array}$ \\
\hline $\begin{array}{l}\text { Sharma et al } \\
2010\end{array}$ & $\begin{array}{l}\text { Lloyd Davis, } 3 \\
\text { ports, } \\
\text { Anterior } \\
\text { gastrostomy } \\
\text { with } \\
\text { ultrasonic } \\
\text { scissors }\end{array}$ & $\begin{array}{l}\text { Through } \\
\text { abdominal } \\
\text { retrieval } \\
\text { incision }\end{array}$ & $\begin{array}{l}\text { Endobag, } \\
\text { Piecemeal }\end{array}$ & $\begin{array}{l}20 \mathrm{~cm}, \\
450 \mathrm{~g}, \\
150 \mathrm{~min}\end{array}$ & $\begin{array}{l}\text { Oral intake } \\
\text { POD5, } \\
\text { Discharge } \\
\text { POD7, Wound } \\
\text { Infection }\end{array}$ & $\begin{array}{l}21 \text { months, } \\
\text { Uneventful. }\end{array}$ \\
\hline $\begin{array}{l}\text { Panse et al } \\
2011\end{array}$ & $\begin{array}{l}\text { Lloyd Davis, } 3 \\
\text { ports, } \\
\text { Anterior } \\
\text { gastrostomy } \\
\text { with } \\
\text { ultrasonic } \\
\text { scissors }\end{array}$ & $\begin{array}{l}\text { Through } \\
\text { abdominal } \\
\text { retrieval } \\
\text { incision }\end{array}$ & Direct & $\begin{array}{l}180 \mathrm{~cm}, \\
600 \mathrm{~g}, \\
130 \mathrm{~min}\end{array}$ & $\begin{array}{l}\text { Oral intake } \\
\text { POD5, } \\
\text { Discharge } \\
\text { POD7, Wound } \\
\text { Infection }\end{array}$ & 24 moths \\
\hline
\end{tabular}


RESULT: The laparoscopic approach to remove gastric bezoars has a better outcome with many benefits over laparotomy and is slowly becoming the treatment of choice. Randomized trials are not possible due to the paucity of cases. Once the underlying disease is dealt with surgically, the cause should be looked into with a multidisciplinary approach to prevent further episodes.

\section{REFERENCES:}

1. Phillips MR, Zaheer S, Drugas GT: Gastric trichobezoars: case report and literature review. Mayo ClinProc 1998, 73:653-656.

2. Nirasawa Y, Mori T, Ito Y, Tanaka H, Seki N, Atomi Y. Laparoscopic removal of a large gastric trichobezoars. J Pediatr Surg. 1998; 33(4):663- 665.

3. Lin CS, Tung CF, Peng YC, Chow WK, Chang CS, Hu WH. Successful treatment with a combination of endoscopic injection and irrigation with coca cola for gastric bezoar-induced gastric outlet obstruction. J Chin Med Assoc. 2008; 71(1):49 -52.

4. O'Sullivan MJ, McGreal G, Walsh JG, Redmond HP. Trichobezoar. J R Soc Med. 2001; 94(2):68 -70 .

5. Rabie ME, Arishi AR, Khan A, Ageely H, Seif El-Nasr GA, Fagihi M. Rapunzel syndrome: the unsuspected culprit. World J Gastroenterol. 2008; 14(7):1141-1143.

6. Palanivelu C, Rangarajan M, Senthil Kumar R, Madankumar MV. Trichobezoars in the stomach and ileum and their laparoscopy-assisted removal: a bizarre case. Singapore Med J. 2007; 48(2):e37- e39.

7. Yao CC, Wong HH, Chen CC, Wang CC, Yang CC, Lin CS. Laparoscopic removal of large gastric phytobezoars. Surg Laparosc Endosc Percutan Tech. 2000; 10(4):243-245.

8. Shami SB, Jararaa AA, Hamade A, Ammori BJ. Laparoscopic removal of a huge gastric trichobezoars in a patient with trichotillomania. SurgLaparosc Endosc Percutan Tech. 2007; 17(3):197-200.

9. Yau KK, Siu WT, Law BK, Cheung HY, Ha JP, Li MK. Laparoscopic approach compared with conventional open approach for bezoar-induced small-bowel obstruction. Arch Surg.2005; 140(10):972-975.

10. Meyer-Rochow GY, Grunewald B. Laparoscopic removal of a gastric trichobezoars in a pregnant woman. Surg Laparosc Endosc Percutan Tech. 2007; 17(2):129 -132.

11. Song KY, Choi BJ, Kim SN, Park CH. Laparoscopic removal of gastric bezoar. Surg Laparosc Endosc Percutan Tech. 2007Feb; 17(1):42- 44.

12. Kan JY, Huang TJ, Heish JS. Laparoscopy assisted management of jejunal bezoar obstruction. Surg Laparosc Endosc Percutan Tech. 2005 Sep; 15(5):297-298. 


\section{CASE REPORT}

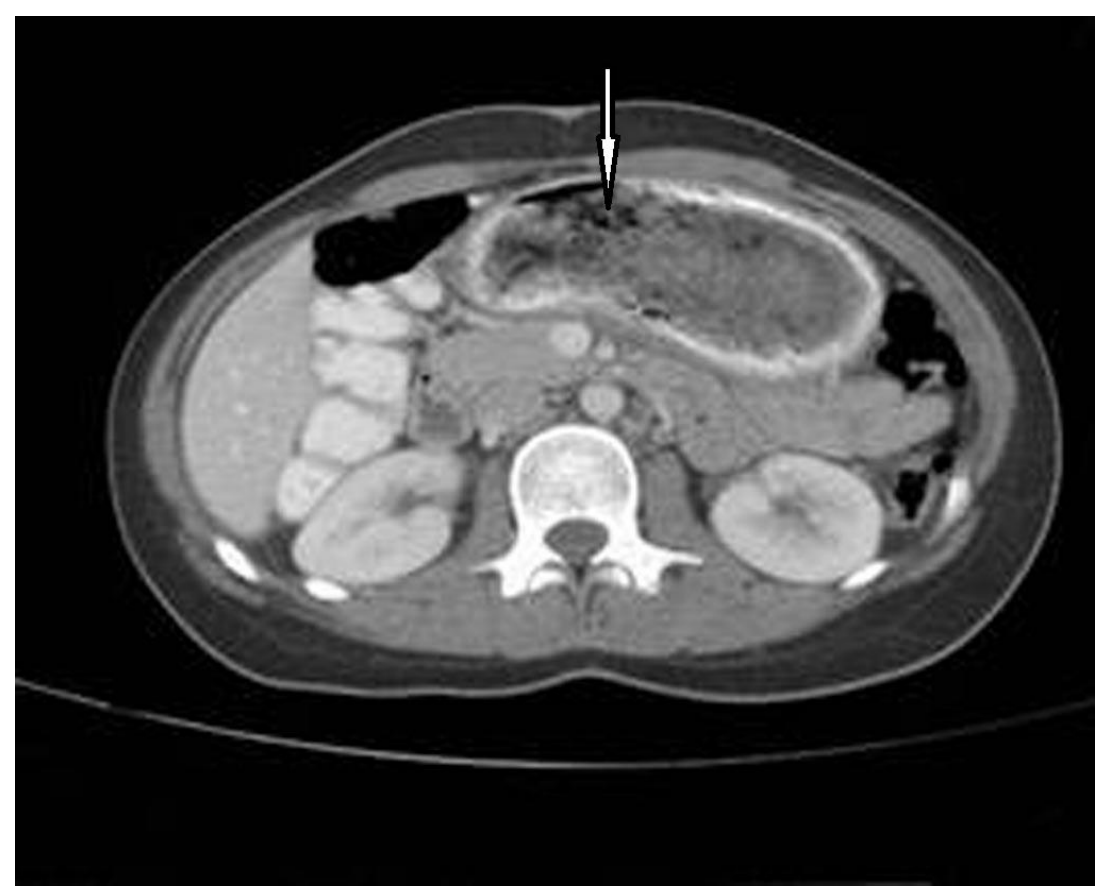

FIG 1-CT Image of Rapunzel

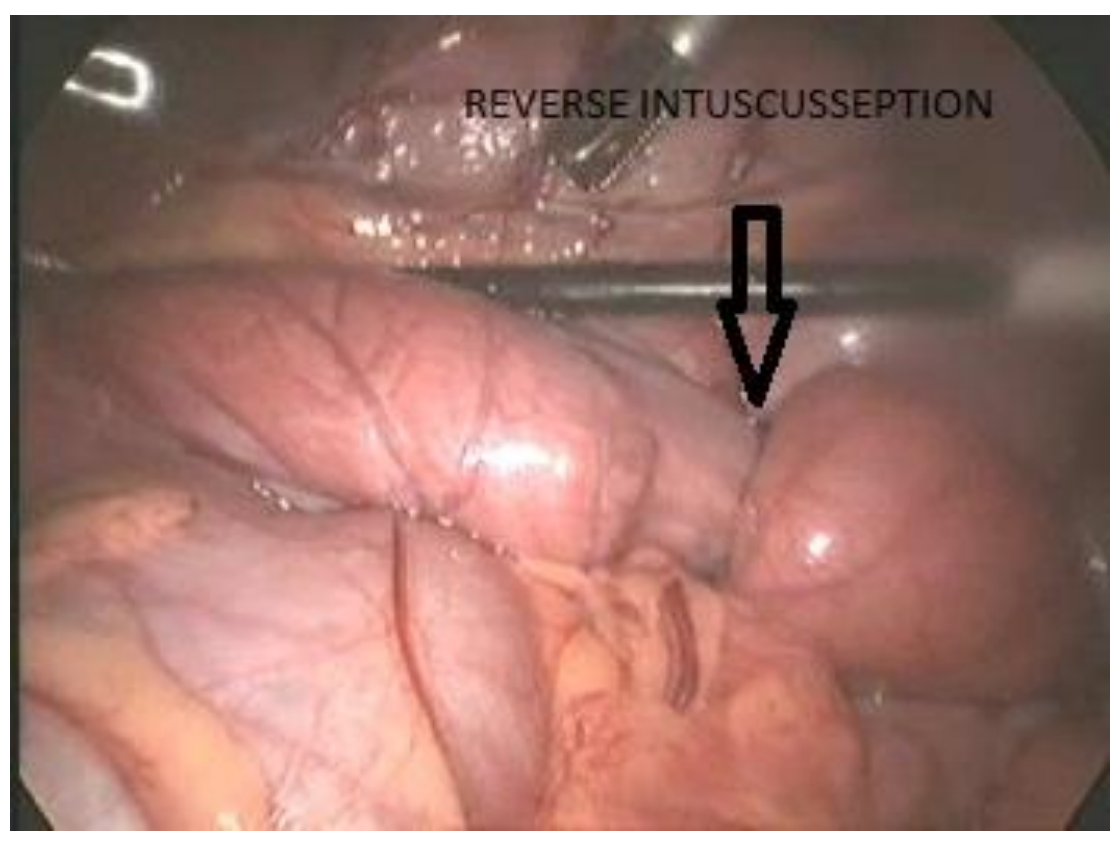

Fig 2-Reverse intuscusseption 


\section{CASE REPORT}

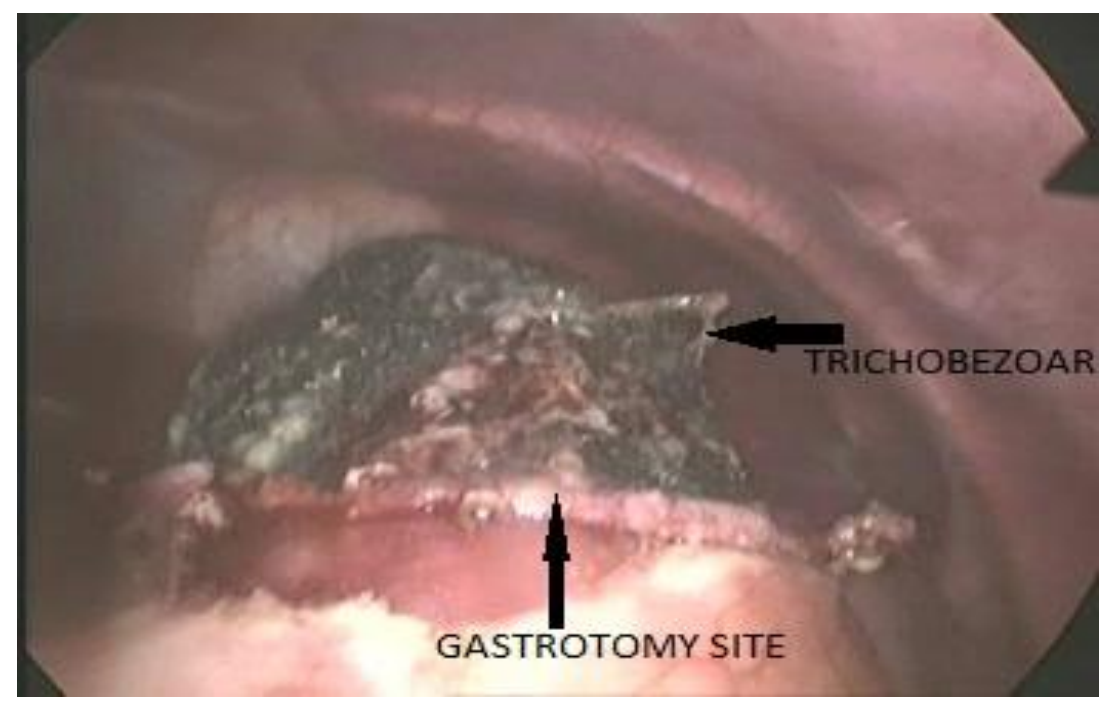

Fig 3-Gastrotomy with Bezoar protruding through it

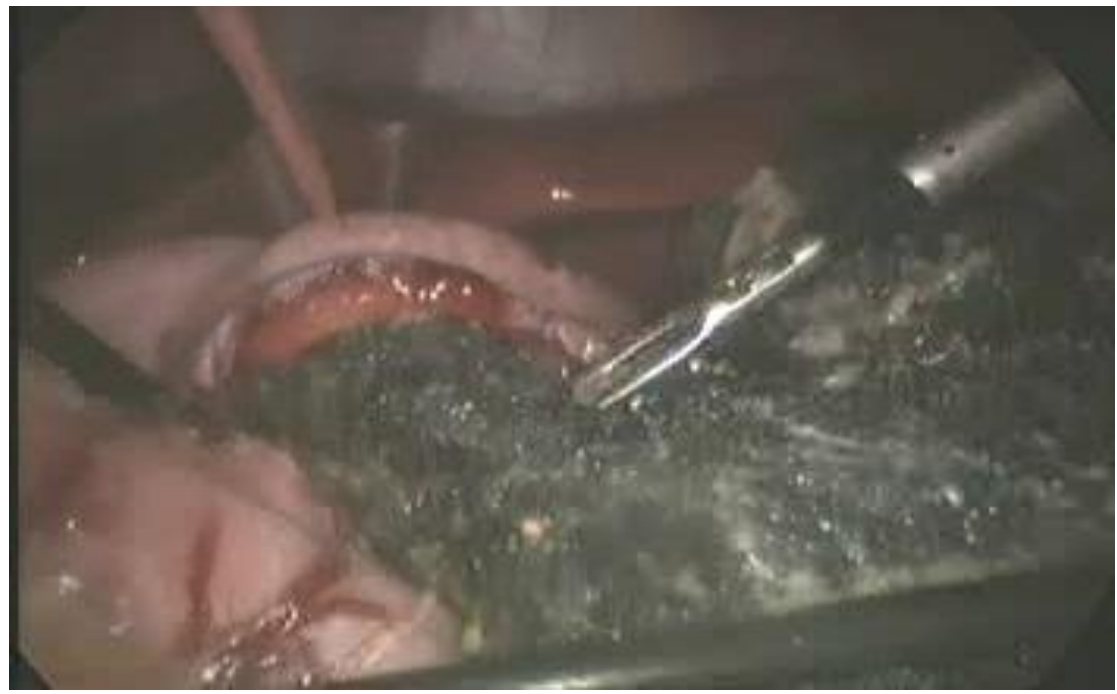

Fig 4-Retrieval of bezoar 


\section{CASE REPORT}

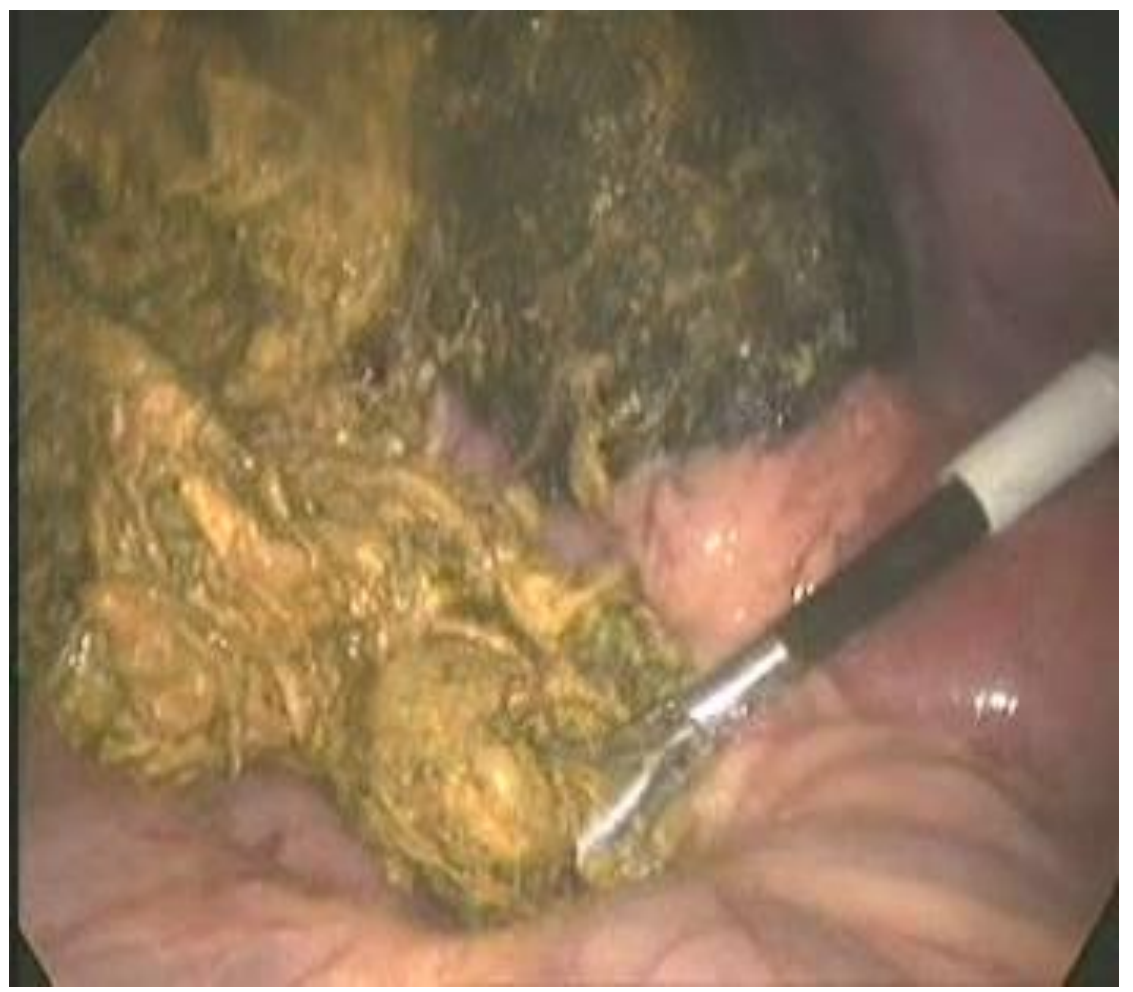

Fig 5- Retrieved trichobezoar in abd

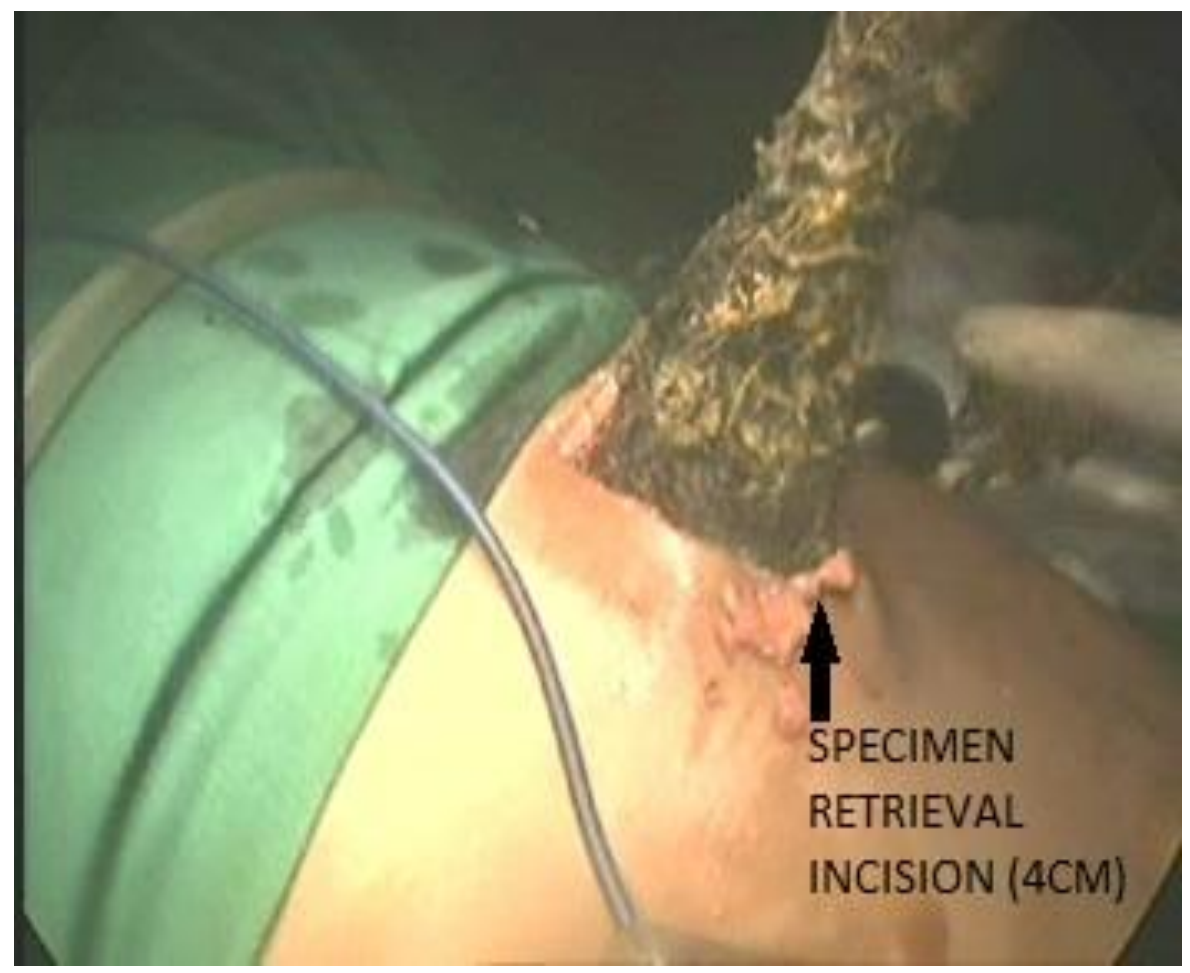

Fig 6- Retrival of bezoar through abd wall incision 


\section{CASE REPORT}

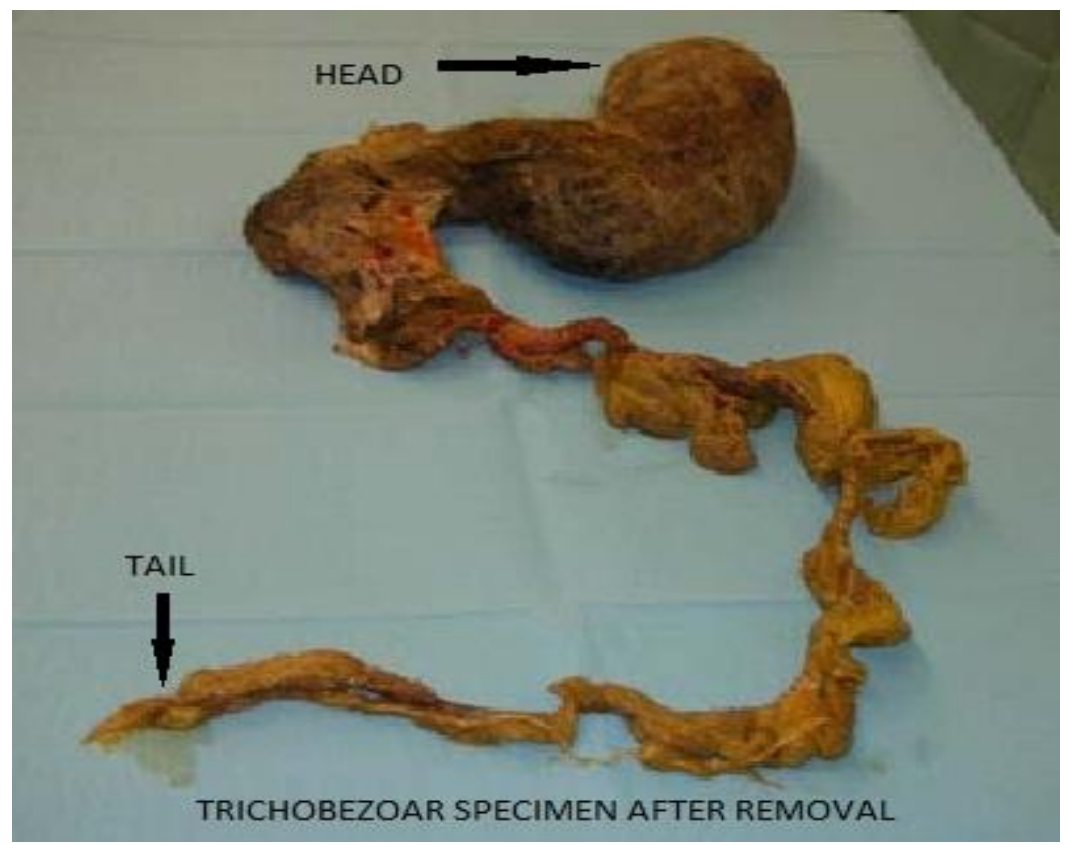

Fig 7- complete trichobezoar specimen

\section{AUTHORS:}

1. Mangesh Panse

2. Sanjay Padale

3. Anirudha Mandhane

4. Pankaj Bhalerao

\section{PARTICULARS OF CONTRIBUTORS:}

1. Head of the Department, Department of General \& Laparoscopic Surgery, Yashvantrao Chavan Memorial Hospital Pimpri, Pune.

2. Surgeon, Department of General \& Laparoscopic Surgery, Yashvantrao Chavan Memorial Hospital Pimpri, Pune.

3. Registrar, Department of General \& Laparoscopic Surgery, Yashvantrao Chavan Memorial Hospital Pimpri, Pune.
4. Surgeon, Department of General \& Laparoscopic Surgery, Yashvantrao Chavan Memorial Hospital Pimpri, Pune.

\section{NAME ADRRESS EMAIL ID OF THE CORRESPONDING AUTHOR:}

Dr. Mangesh Panse,

Y.C.M.H. Department of Surgery, Pimpri,

Pune- 411018.

Email-drpmangesh@yahoo.co.in

Date of Submission: 29/06/2013.

Date of Peer Review: 29/06/2013.

Date of Acceptance: 01/07/2013.

Date of Publishing: 10/07/2013 